\title{
海浜の原風景の変容に関する研究* 一古来より讃えられた海浜の原風景と大学生の原風是との比較を通じて一
}

A Study on the Transition of the Original Scenery of the Beaches -Comparison between the Original Scenery of Conventional Beaches and the Original Scenery of University Students-

\section{三溝裕之 ${ }^{1}$ 横内憲久 ${ }^{2}$ 桜井慎一 $^{3}$ 岡田智秀 $^{4}$ 喜多川智一 $^{5}$}

By Hiroyuki Samizo,Norihisa Yokouchi,Shin-ichi Sakurai, Tomohide Okada and Tomokazu Kitagawa

\section{1. 研究目的}

わが国の自然海浜は、和歌や名所図会等において 白砂青松や長汀曲浦といった個性豊かな景観が古来 より讃えられており、それは、これまで日本人が永 い年月に渡って共有しつづけてきた海浜の原風景の 一つといえよう。一方、近年の海浜においては、海 岸防災を根底に据えつつレクリエーション利用等に も供される整備が行われており、これにより背後地 域は自然災害等から保護され、海辺は市民に開放さ れつつある。このような海岸整備は国土保全や親水 空間の提供においては多大な功績を残したものの、 そこから眺められる景観は、コンクリート剥き出し の護岸や突堤など、どこの地域でも同じような形 態・デザインが現出し始めている。こうした海岸構 造物が表出する画一的な姿は、結果として、かつて 人々を魅了した自然海浜とはかけ離れた景観を露呈 させ、このような海浜を経験した人々が、古来より 讃えられた海浜の原風景を継承していくことは困難 になりつつあると思われる。幾世代にも渡って人々 が抱いてきた海浜の原風景はわが国の文化的財産で あり、それは今後継承していくべきものといえよう。

そこで本研究は古来より讃えられてきた海浜の原 風景を構成する景観要素を捉え、それらの要素が現 代の海浜景観を体験した人々が抱く海浜の風景(原 風景)において、現在どの程度伝承されているのか、 その継承・変容状況を把握することを目的とする。

\footnotetext{
*キーワーズ：景観、空間設計、原風景

1 学生会貝是本大学大学院 理工学研究科海洋建築工学専攻

(汗274千葉県船樈市習志珪台 7-24-1. TEL \& FAX : 0474-69-5427[自動切替])

2 正会員 工博 日本大学教授 理工学部海洋建築工学科

3 正会貝 工博 日本大学専任講師 理工学部海洋建築工学科

4 正会員 工博 日本大学研究生 理工学部旃洋建築工学科

5 正会員 工修（㧣)パスコ総合暞境センター沿岸開発部
}

\section{2. 既往研究との関連}

海浜の景観に関する既往研究としては、古来の自 然海浜を対象として、斉藤 ${ }^{(1)}$ が和歌や名所図会等に より、海岸景観およびその体験のしかたの典型につ いての知見を得ている。他方、現在の自然海浜を対

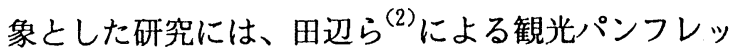
トや C G な゙から砂浜汀線の認知構造を解明したも のや、篠原ら ${ }^{(3)}$ の地形図を用いて自然海浜の空間構 造を分析し、人工海浜を設計する際のデザインボキ ヤブラリーを抽出したものがある。また、海浜景観 を時代の変遷で捉えたものは、毛利ら ${ }^{(4)}$ が歌謡曲の 歌詞を用いて、海のイメージの変容を分析している。 このように古来や現在といった一時点において自然 海浜を分析対象とした研究や、主に近現代における 海のイメージの変容状況について論じたものは存在 するが、本研究が意図するような、かつての自然海 浜と現状の海浜景観を原風景において比較し、その 継承・変容状況を捉えたものは見当たらない。

\section{3. 研究方法}

本研究は以下の方法で進めるものとする。 (1)古来より讃えられた海浜の原風景を構成する景観 要素の抽出

古来から讃えられてきた海浜の原風景を構成する 景観要素を把握するため、名所図会や和歌等を分析 対象とした自然海浜の景観に関する既往研究等から、 自然海浜の景観要素とその形態的特徵・景観的役割 を整理する。

(2)大学生の原風量を構成する最観要素の把握

海岸整備が行われてきた現代の海浜を経験した 人々の原風景はどのような景観要素で構成されてい 
るかを捉えるため、わが国の海浜を経験した中で印 象深い海浜をスケッチさせる ${ }^{(5)}$ 調査(表一1)を行う。 被験者は、海岸環境整備事業が開始(1973)されたこ とにより自然海浜の中に海岸構造物が徐々に投入さ れはじめた時期に、原風景が形成される時期 $(5 \sim 18$ 歳頃) ${ }^{(6)}$ であった 1970 年代生まれの大学生とした。

なお、本研究では被験者がスケッチに描いた海浜 を大学生の原風景とする。

\section{(3)古来より讃えられた海浜の原風量の変容状況}

大学生が抱く原風景において、古来より讃えられ た海浜の原風景がどの程度継承されているのか、そ の状況を把握するために、上記のスケッチに出現し た景観要素と古来より讃えられた海浜の原風景を構 成する景観要素との同一性・相違性を比較考察する。

\section{4. 結果および考察}

\section{（1 古来より諎えられた海浜の原風景の構成要素}

表 $-2{ }^{(7)}$ は、和歌や名所図会等の資料を分析対象 とした自然海浜の景観に関する既往研究等 ${ }^{4) \sim 19)}$ 方 ら抽出した自然海浜の景観要素と、その形態的特 徵・景観的役割を整理したものである（表中「文献番 号」は「引用参考文献」のものと対応）。これより、自 然海浜の景観構成は、海浜においてランドマークや

表 -1 調查の方法と概要

\begin{tabular}{|c|c|}
\hline & 調 查 方 \\
\hline $\begin{array}{l}\text { (1)海泜の原風景の } \\
\text { スケッチ }\end{array}$ & 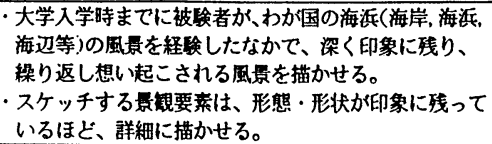 \\
\hline $\begin{array}{l}\text { (2)景観要絜の形態 } \\
\text { 的特幑の確認 }\end{array}$ & $\begin{array}{l}\text { ・スケッチに出現した景観要素は何を表現したものか、 } \\
\text { ならびに、そ形態特徽を説明させる。 }\end{array}$ \\
\hline (3)視点場の把握 & ・風景を眺めている場は、どこか回答させる。 \\
\hline $\begin{array}{l}\text { (4)原風贯の成立 } \\
\text { 要因の把握 }\end{array}$ & 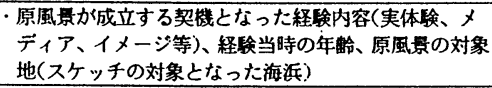 \\
\hline (5)被䀰者の属性 & ·性別、現在の年解 \\
\hline & 調 查 概 要 \\
\hline 調査期間 & 1995 年 $8 \sim 12$ 月 \\
\hline 被蝓者 & 日本大学 理工学部の学生(18 25 歳) \\
\hline 調查場所 & 日本大学 理工学部の教室 \\
\hline 回答者数 & 224人 侽： 170 人(75.9\%)，女: 54 人(24.1\%)) \\
\hline 有効回答数 & \\
\hline
\end{tabular}

表一2 古来から讃えられてきた海浜の原風景の景観要素とその形態的特徴・景観的効果等

\begin{tabular}{|c|c|c|c|}
\hline 貫観要素 & 形 意的特 微 & 量観的効果等 & 文献番号 \\
\hline $\begin{array}{l}\text { (1)疄䢂水域 } \\
\text { (浦) }\end{array}$ & 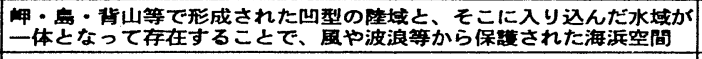 & 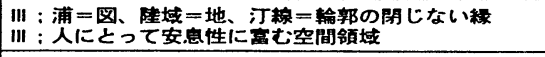 & $\begin{array}{|rr|}\text { 7) } & 8) \\
\text { 9) } & (0)(1) \\
\end{array}$ \\
\hline \multirow[t]{2}{*}{ (2)砂浜 } & 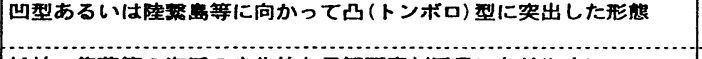 & 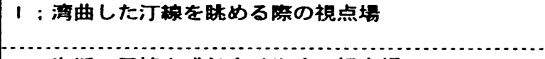 & $\begin{array}{l}\text { 5) 6) 10) } \\
\text { 12) }\end{array}$ \\
\hline & 昖林・集落等の海浜の文化的な量観要素が添量になりやすい & 1：海浜の圆倩を感しさせやすい視点場 & 7) 13) 14) \\
\hline \multirow[t]{2}{*}{ (3)汀粮 } & 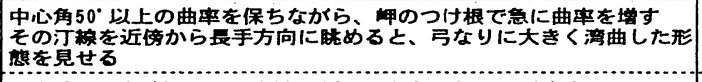 & 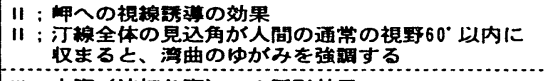 & $\begin{array}{ll}\text { 5) } & 15) \\
7\rangle & 15)\end{array}$ \\
\hline & 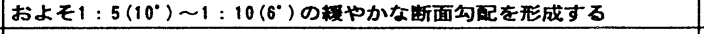 & 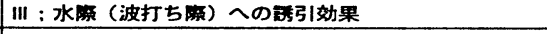 & 7) 15) 16) \\
\hline \multirow[t]{2}{*}{ (4) 磯 } & 海し地形は巧みに入り耝み明䃥な境界かなく海面に岩か点在する & 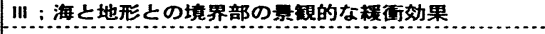 & 16) \\
\hline & 水深の浅い磯には、白波が立つことが多い & III：船舶が出入港する祭のランドマーク & 11) 14) \\
\hline (5) 袖 & 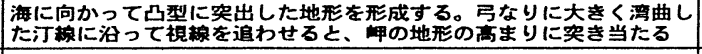 & 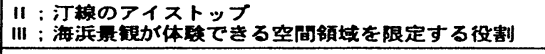 & 4) \\
\hline \multirow[t]{2}{*}{ (6)1年山 } & 水城を取り里むような連なりを見せる海浜背後の山並み & III! : 海浜量钼が体倹できる空間領域を限定する役割 & 6). \\
\hline & $\begin{array}{l}\text { 仰角 } 5^{\circ} \text { 以下に山顶が胃える } \\
\text { 仰角 } 9^{\circ} \text { 近傍に山顶が睍える } \\
\text { 仰角 } 20^{\circ} \text { 近傍に山顶がる } \\
\end{array}$ & 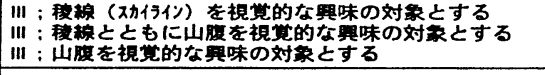 & $\begin{array}{l}\text { 19) } \\
19) \\
19)\end{array}$ \\
\hline (D) & 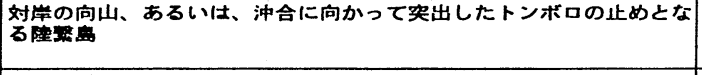 & 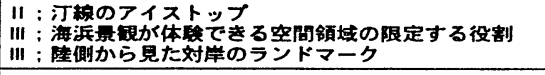 & \begin{tabular}{ll|} 
9) & $12)$ \\
6) & \\
9) & 12) \\
\end{tabular} \\
\hline (8)丘 & 来落等の湑量か形成される海辺近くの丘陵地 & 1：海浜への眺望の良い視点場 & 10) 14) \\
\hline (9)㙂れ岩 & 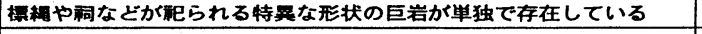 & III：海上のランドマーク & 4) 12) 14) \\
\hline \multirow{4}{*}{ (1)榯森) } & 昖林の根本には下生えがなく、松を種うように杪浜が広かる & I : 人の出入りしやすい視点䭪. & 7) \\
\hline & 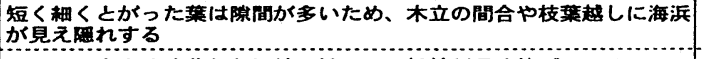 & 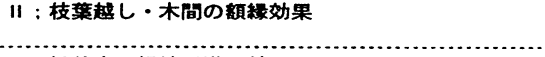 & 7) 15) \\
\hline & 弓なりに大きく湾曲した汀楾に沿って、松林が長く伸びている & 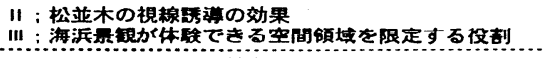 & 7) \\
\hline & 砂浜に接する昖林の生え㻮は、吅みに入り粗み明碓な境界かない & 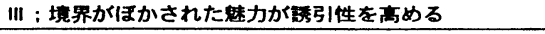 & 7) \\
\hline (11)陫れ松 & 松林から所々砂浜に踊り出たように存在する & III；眇浜の添量 & 13) 15) \\
\hline (12)集落 & 基落を形成する建物は、海辺から龍れた場にあるものほど高㕍になる & III：生活领域を視觉的な興味対象とする & 17) \\
\hline (13湖見坂 & 山裾の坂进において、建ち並ふ民家の埴間から海浜が見え罒れする & 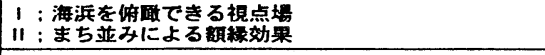 & 7) \\
\hline \multirow[t]{4}{*}{ (4)日和山 } & 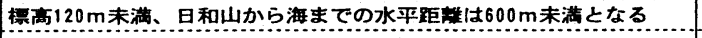 & I：楽に登り降りでき船舶の活動が把握できる視点場 & 9) \\
\hline & 頂上からは内海と外海の両方が俯酷できる & 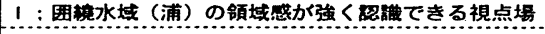 & (4). \\
\hline & 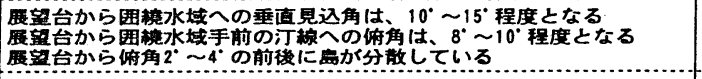 & I：目塂水域（浦）が主対象しして伥められる梘点場 & 18) \\
\hline & 頂上には、辳望台・大榔・雨夜灯等が存在することが多い & III；船舶が入港する祭のランドマーク & 9) 18) \\
\hline
\end{tabular}

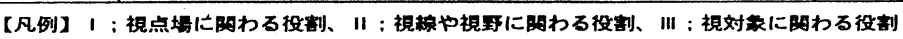


アイストップとなる「师」島」人々を水辺に誘引す る弓なりに大きく湾曲した「砂浜「汀線」、また、こ れらの地形に囲まれ、人々に安息感を与える「囲繞水 域(浦)」などの 14 の「景観要素」であることが把握で き、さらに、それらの「形態的特徵」および景観的効 果等」が明確となった。これより古来より讃えられた 海浜の原風景は自然海浜の 14 要素であることが把 握できた。

以降は、これらの自然海浜の 14 要素のうち、大学 生はどのような景観要素を伝承・変容したのかを把 握するため、大学生の原風景を捉えるものとする。

\section{(2)大学生の原風景を構成する景観要素の把握 (a )大学生の原風量の成立と海岸整備との関係}

90.9 1.3.

図一 1 大学生の原風景が形成される契機となった経験内容

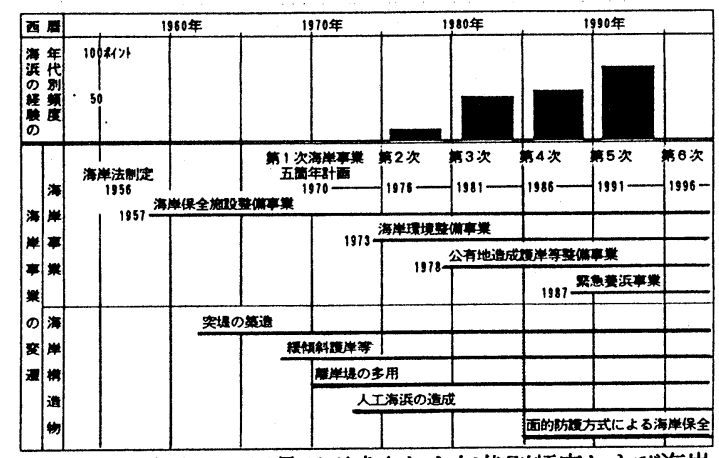

図一 2 大学生の原風景が形成された年代別頻度および海岸 事業の変遷

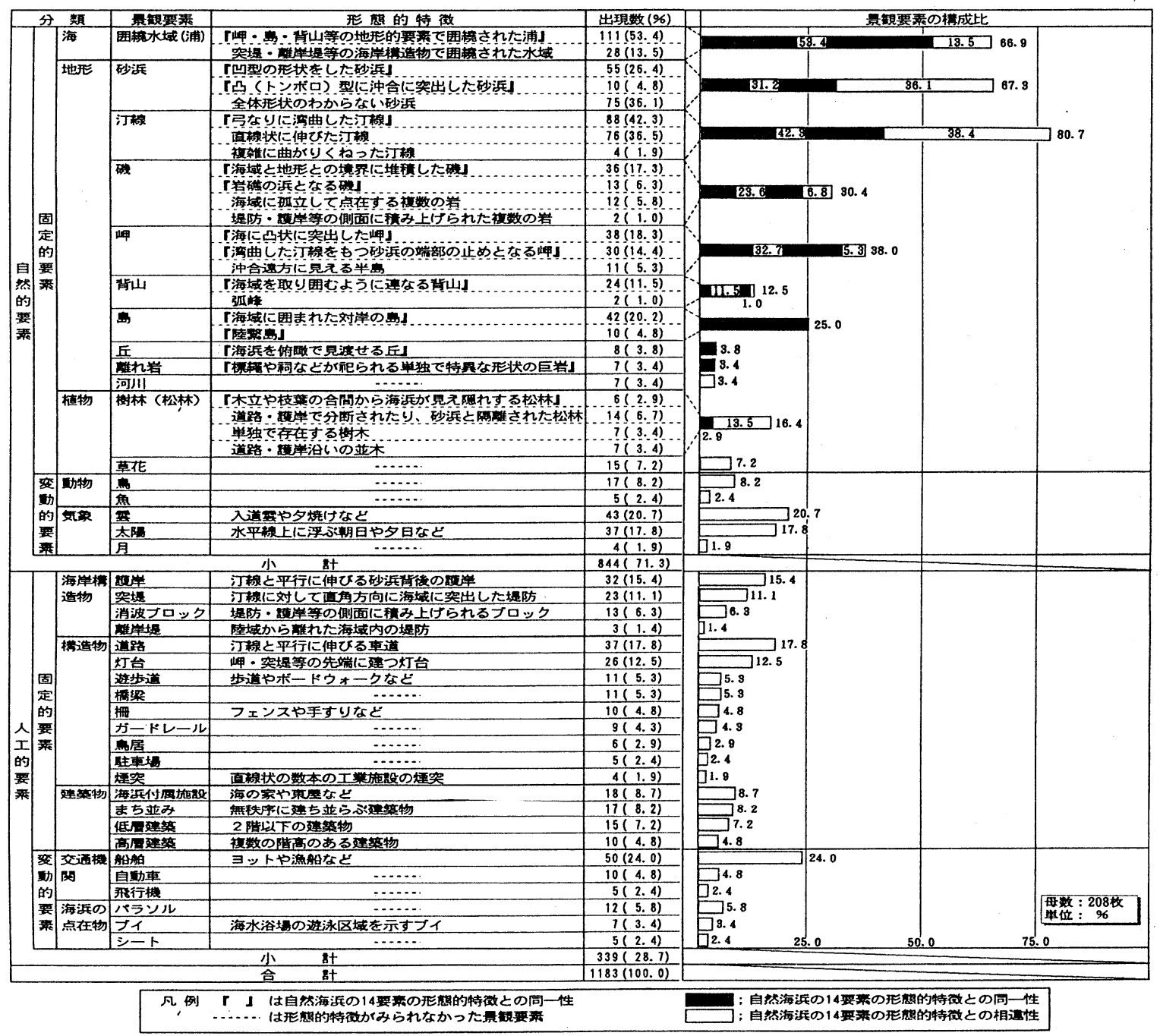

図一-3 大学生の原風景に現れた景観要素の出現数(出現率)および自然海浜の景観要素との同一性・相違性の構成比 


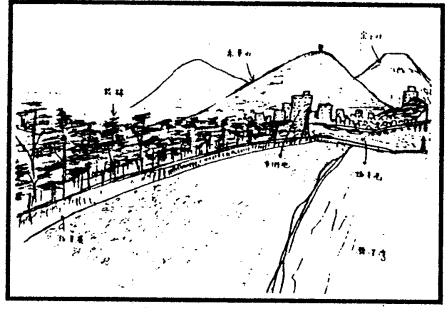

図一４護岸によって分断された 松林と砂浜のスケッチ例

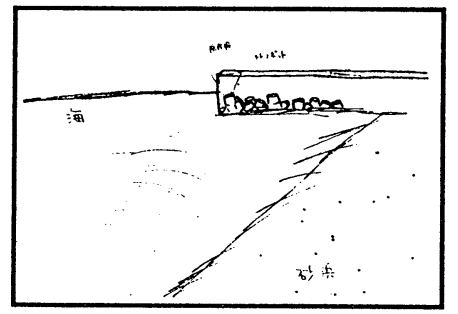

図一 5 湾曲形として認識されてな い砂浜・汀線のスケッチ例

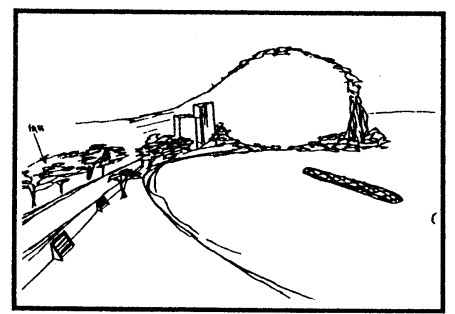

図一6 主として離岸堤等の海岸粠 造物により形成された囲繞 水域のスケッチ例
図一 1 は、原風景が成立する契機となった印象深い 海浜景観の経験内容の内訳を示している。これをみ ると、全体の約 9 割が実体験に基づいて形成されて いることがわかる。つまり、原風景は「イメージ」 (5.3\%)や「メディア」(3.3\%)といったものではなく、 実際に体験した海浜よりもたらされたものといえる。 また、印象深い海浜景観を経験した年代別頻度およ びその年代に該当する海岸事業の変遷(図一-2)をみ ると、被験者の多くは、1980 年代から現在までの期 間に原風景が形成されており、この期間は、海岸法 に基づく海岸事業が実施されてから約 20 年後の第 3 次から第 5 次海岸事業の実施時期に該当し、護岸 や離岸堤等の海岸構造物が海浜に設置された頃と一 致する。これより、大学生の原風景は海岸構造物が 徐々に設置されてきた時期に実体験に基ついて形成 されていることが確認できた。

そこで、このような大学生の原風景には、如何な る海浜の原風景の景観要素が継承され、あるいは、 消失・変容したのかを明らかにし、その要因を考察 する。

\section{(b )大学生の原風景に出現した最観要素}

大学生の原風景がどのような景観要素から構成さ れているのかを把握するために、そのスケッチに出 現した景観要素を「海」「地形」等の「自然的要素」と、 「海岸構造物」「構造物」等の「人工的要素」に分類・整 理し、それらと 14 要素に関して形態的特徵(表一2) に同一性・相違性がみられた景観要素の出現数(出現 率)とそれらの構成比を示したものが図ー3である。

「自然的要素」人工的要素」の出現率の小計を比較 すると、前者は $71.3 \%$ 、後者が $28.7 \%$ ある。これ より大学生の原風景には自然的要素ばかりでなく、 人工的要素も出現してきていることを明らかにした。

\section{(3)古来より讃えられた海浜の原風景の变容状況}

図ー 3 をみる之、自然海浜の 14 要素のうち、原風 景に出現した景観要素は「囲繞水域(浦)」砂浜」「汀 線」「磯」「岬」「背山」「島」「丘」「離れ岩」「樹林(松林)」 の 10 要素であり、一方、集落」潮見坂」「日和山」離 れ松」の 4 要素は原風景から消失してしまったこと がわかる。これら 4 要素が原風景から消失した要因 を考察すると、それらの存在が希少であるとも考え られるため一概にはいえないが、「集落」は、かつて 一つのまとまりとして存在していた生活領域が、都 市化に伴い建物が面的に建ち並ひ、その領域が認識 されにくくなったため、また、まち中から海浜を垣 間見ることのできる「潮見坂」や「日和山」も、こうし た背後の都市化により、視点場としての役割・機能 を果たせなくなってしまったこと、さらに、松林か ら海に向かって所々躍り出たような「離れ松」は松林 が箱庭のように植樹されているため消失、もしくは 認識されなくなったと考えられる。

そこで以降は、原風景に出現した上記の 10 要素の 変容状況を把握するために、各景観要素ごとに自然 海浜の景観要素の形態的特徴と同一性が認められた もの(図ー3中の口印) と相違性が認められたもの (困一 3 中の $\square$ 印) との構成比や被験者のスケッチを 基に考察する。なお、図ー4〜6はスケッチの典型 例である。

原風景に出現した自然海浜の 10 要素のうち、最も 相違が顕著であった「樹林(松林)」は、本来の姿を残 しているのは僅か (2.9\%)で、多くはかけ離れた姿 (13.5\%)になってしまっている。これは、「道路・護 岸で分断されたり、砂浜と隔離された松林」(6.7\%) というように、松林と砂浜の境界部分に階段護岸等 が設置されたため、砂浜と巧みに人り組む松林の生 え際が失われたことに起因する(図ー4)。 
次いで、「砂浜」「汀線」は「全体形状のわからない仯 浜」(36.1\%)、「直線状に伸びた汀線」複雑に曲がり く权った汀線」(38.5\%)など、半数近くの被験者によ り本来の形態とは異なった姿として認識されつつあ る。これは、「砂浜」汀線」の形状を大きく変化させ る離岸堤・突堤等の海岸構造物がその形状変化を考 慮せずに砂浜の安定化を図ること.のみで配置決定さ れるという、現状の海岸整備による影響と思われる (図-5)。

『岬・島・背山等の地形的要素で囲繞された浦』 (53.4\%)は、半数以上により本来の姿として認識さ れているが、その一方で突堤・離岸堤等の海岸構造 物で囲繞された水域」(13.5\%)のように、「囲繞水域」 を構成する要素が地形的要素から海岸構造物へと 徐々に変容してきていることがわかる(図-6)。

以上より、海浜の原風景を構成する景観要素の変 容状沉をはじめ、その変容をもたらしたのは現状の 海岸整備に起因するという変容要因が考察できた。

\section{5.まとめ}

本研究では以上の結果から次に示す知見を得た。 1)古来より讃えられてきた海浜の原風景を構成 するものとして自然海浜の 14 要素を抽出し、 これらの要素の形態的特徴とその景観的な効 果や役割を把握することができた。

2 )大学生の海浜の原風景は約 9 割が実体験によ り形成されていることが判明し、今後の海浜 空間における景観整備の重要性が認識できた。

3 )大学生が抱く海浜の原風景において上記の 14 要素のうち、集落」潮見坂」「日和山」離れ松」 の 4 要素は消失する傾向にあり、また、継承さ れた 10 要素のなかでも、「樹林(松林)」「汀線」 「砂浜」囲繞水域(浦)」の 4 要素はそれらの形態 が顕著に変容してきていることを明らかにし た。これらが消失・変容した要因としては、水 理的観点や利用面に重点を置いて実施されて きた従来の海岸整備の影響によるところが大 きいことを考察した。

6. おわりに

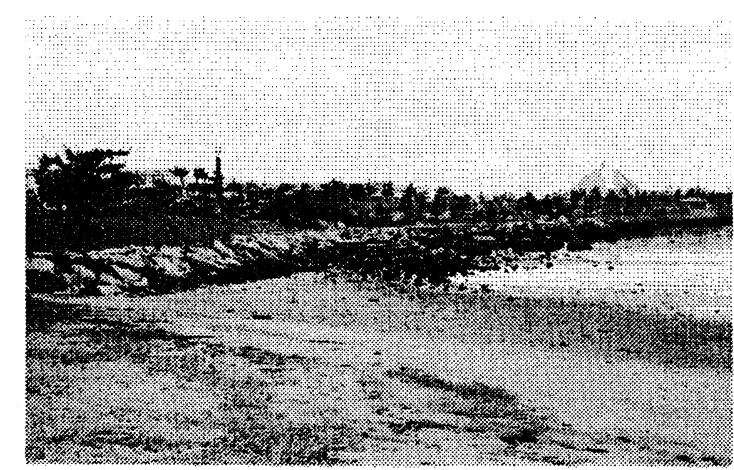

写真-1 䟧に見立てられる突堤(横浜市・海の公園)

四方を海に囲まれたわが国において海浜の景観は、 国土の輪郭を形成するなど、きわめて重要な意味を 持つため、とりわけ自然地形を人工的に改変する恐 れがある海岸整備においては、時代に左右されない 確固たる景観デザインの規範が必要といえよう。

本研究では以上の認識に基づき、こうした景観デ ザインの規範を古来から讃えられた自然海浜の原風 景に求めたが、これはかつての海浜の姿を忠実に再 現するといった考えではない。つまり、防災対策や レクリエーション機能など、現在の海岸構造物に求 められる諸機能を満足させつつ、古来より讃えられ た海浜の原風景を構成する要素の景観的な役割や効 果等を海岸構造物に持たせようとするものである。

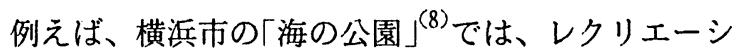
ョン利用を目的とした人工砂浜を造成するため、砂 浜両端部に突堤を配置し、その天端上に盛土や植栽 を施すことにより、自然海浜の岬のようなデザイン を施している(写真－1)。これは本研究が意図する ような海岸整備の一方策と捉えることができよう。

今後こうした整備を行うことは、現代の海浜にお いて失われつつある自然海浜の景観美を取り戻すと ともに、後世の人々に古来より讃えられた海浜の原 風景を継承させていくことにつながるものと考える。 最後に、本研究では景観要素の変容状況を捉える にあたり、個々の要素に着目して検討を行っている が、これに加えて、要素相互の位置関係や構図等の 考察が必要であるといえ、今後の課題としたい。

\section{一補註}

(1) 文嗝 4 )

(3)文矿 6 )

(4) 文补 3)

（5）文献 1)，2)ではスケッ千を用いた自由記述方式により费年(大学生)の 心象風景の構造を解明している。そこで本研究においても原風貫をスケ

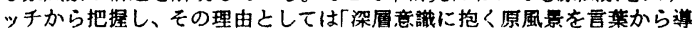
き出すことは困㒕であるのに対し、スケッチは被硂者か值裁に表現てき ろこと」「スケッチからは原風景の詈観要秦の形菂的特徽が把握でき、被 
検者自身も描きながらそれを再確認できること」が挙げられる。

(6)文献 1)

(7)表一2の作成にあたっては、篚者らが既往研究等の内容を、その主旨に 沿ってまとめ直したものである。

(8)文献 20)

一 引用参考文献

1 茂原朋子ほか 2 名;「费年の“原風量” の特性之構造に関する研究」, 日本 都市計画学会学術研究諭文集 No26.pp. $457 \sim 462,1991$

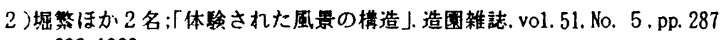
$\sim 292.1988$

了㕰利隆子. 後藤春彦:「歌にあらわれる「海」のイメージの桨容」.日本都市 計画学会学術研究諭文集 No29, pp. 595 600, 1994

4 )斉藤潮:「海岸鲸観およびその体験の典型に関する研究」, 日本都市計画学 会学術研究諭文集 No. 20. pp. $391 \sim 396,1985$

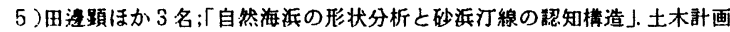
学研究・講演果 No. 17.pp. $1095 \sim 1098.1995$

6 )篠原修ほか 2 名;「人工海浜のアーステザインに関する研究」土木学会第 46 回年次学術綪誼集. pp. $482 \sim 483.1991$

7 ) 中村良夫:「風景学入門」. pp. 28〜220, 中公新青, 1982

8 )芦原我信:「続・街並みの美学」.pp. 53〜 70, 岩波新畵. 1983
9 )斉藤湖;「港の鲸穓と地形の意味」「土木学会編 港の景锶設計」, pp. 8 23, 技法堂出版. 1991

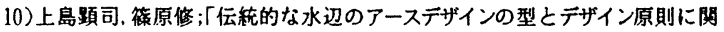
する研究」. 土木計画学研究・諭文集 No. 8. pp. $249 \sim 256.1990$

11) 原田弘之. 盛岡通;「近世の名所図会を題材とした湾の累锶分析」土木計 画学研究・論文集 Nol1, pp. $169 \sim 174.1993$

12)斉藤湖;「海岸の景䚁」「海岸の懪境創造」,pp. 9 19, 朝倉青店. 1994

13)高橋進:「風素美の創造と保護」, 大明堂, pp. $152 \sim 193.1982$

14)世谷康之ほか 2 名:「海岸における聖域の研究」, 日本都市計画学会学術研 究訶文集 No. 26. pp. $451 \sim 456.1991$

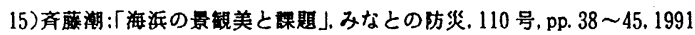

16)和夫ほか 4 名;「新たなデインコンセプに基つく人工海浜 C G 景锶設計 の試み」, 土木計画学研究・講演集 No. 16.pp. 357 363. 1993

17)須藤柘ほか 2 名;「近世以前の水墨画によろ水辺の景観構成について」. 日 本都市尌画学会学術研究論文集 No. 25. pp. 667 672. 1990

18)篠原修:「新体系土木工学 59 土木景锶計画」. pp. $87 \sim 195$, 技報堂, 1982

19)桶口忠彦;「蓲観の構造」,pp. 40 63, 技報堂, 1975

20)土木学会・土木計画学研究委員会:「土木計画学ワンティセミナー第 5 回 ・海浜の睘観デザインの課題」, 1995

海浜の原風景の変容に関する研究 一古来より讃えられた海浜の原風景と大学生の原風景の比較を通じて一 三溝裕之 横内憲久 桜井慎一 岡田智秀 喜多川智一

各地で整備されつつある人工海浜は、無味乾燥なコンクリートを露呈した海岸構造物が諸所に配

置されるなど、かつての自然海浜のものとは大きく掛け離れた姿となり始めている。

本研究ではこうした状況を踏まえ、古来より讃えられた自然海浜を原風景として後世の人々に継

承するために、かつての自然海浜と大学生の原風景を比較し、その変容状況を明らかにした。

本研究で得られた主な成果は次の通りである。

(1)これまで讃えられてきた自然海浜の景観要素とその形態的特徴等の抽出・整理

(2)大学生の原風景の成立要因之海浜整備との関連性

(3)大学生が抱く原風景からみた自然海浜における景観要素の伝承・変容状況およびその要因の把握

A Study on the Transition of the Original Scenery of the Beaches

-Comparison between the Original Scenery of Conventional Beaches and the Original Scenery of University Students-

By Hiroyuki Samizo,Norihisa Yokouchi,Shin-ichi Sakurai, Tomohide Okada and Tomokazu Kitagawa

On artificial beaches, which are created in various locations, seashore structures are being established. The scenery of such beaches, therefore, is becoming different from that of conventional natural beaches. Based on such a state of beaches, purpose is made in this study on the transition between conventional natural beaches and the original scenery of university students in order to succeed the scenery of natural beaches.

Results of this research are as follows;

1) The sorting-out of scenery composition of conventional natural beaches and characteristics of their forms.

2) The connection between the original scenery of university students and maintenance of beaches.

3) The state of changes in scenery factors of natural beaches, viewed by university students in the original scenery, and grasping of such factors. 